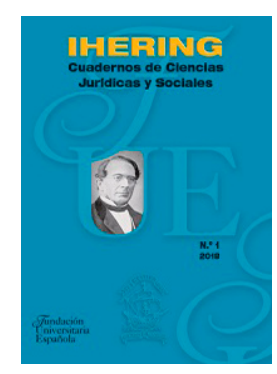

\author{
Ihering. Cuadernos de Ciencias Jurídicas y Sociales \\ $\mathrm{N}^{\mathrm{o}} 1$
}

Año: 2018

e-issn: 2660-552X

DOI: https://doi.org/10.51743/ihering.10

(c) (1) ()

\title{
Europa, 1945: la necesidad de recordar
}

\author{
José CARlos MuÑoz CASTELlanos
}

RESUMEN. 1945 es un año conocido como el "Año Cero": supuso el fin de la Segunda Guerra Mundial y el inicio, para la Europa occidental, de un ideal que conduciría a la construcción de unas sociedades más justas y prósperas. Pero el año 1945 también fue un año de grandes sufrimientos para los europeos. Recogemos en este trabajo los testimonios de personas que vivieron esos agitados años, para ofrecer al final una reflexión de 1945 desde nuestro más inmediato presente.

PALABRAS CLAVES: 1945, europeos, destrucción, esperanza, recordar.

ABSTRACT: 1945 is a year known as the "Year Zero": it marked the end of the Second World War and the beginning, for Western Europe, of an ideal that would lead to the construction of fairer and more prosperous societies. But the year 1945 was also a year of great suffering for Europeans. We gather in this work the testimonies of people who lived those hectic years, to offer at the end a reflection of 1945 from our most immediate present.

KEY WORDS: 1945, Europeans, destruction, hope, remember.

\section{INTRODUCCIÓN: LA DESTRUCCIÓN COMO EXPERIENCIA HUMANA EN 1945}

T os historiadores acostumbran a caracterizar momentos concretos en el Ltiempo como cesuras que dividen la realidad histórica en épocas diferentes: la caída de Roma en 476; la de Constantinopla, y por tanto de Bizan- 
cio, en 1453; la llegada de los castellanos a América en 1492, los inicios de la Edad Contemporánea en $1789 \ldots$ y, la que aquí nos interesa, el fin de la Segunda Guerra Mundial en 1945. Esta es una costumbre ampliamente aceptada, con riesgos asociados, que si bien puede resultar muy útil para racionalizar el estudio histórico, también puede conducirnos a planteamientos rupturistas que quizá desdibujen la realidad. No obstante, en ocasiones es fructífero este proceder, centrándolo especialmente en años en torno a los cuales alcancen un punto de solución problemas históricos de largo recorrido. Por ejemplo, Henri Focillon dedicó una monografía al año mil (momento no sólo de miedos apocalípticos, sino también de importantes transformaciones económicas y sociales en la Edad Media), señalando que hay "años críticos, verdaderos nudos de acontecimientos", así como a lo largo de un mismo año hay etapas de "respiración" y etapas de "jadeo". ${ }^{1}$ De acuerdo con esta visión, para la sociedad europea 1945 fue un año marcado por los jadeos.

En el caso del año 1945, quizá, la justificación de su impacto mundial es mayor que en los ejemplos anteriores: es decir, el fin de la guerra afectó a prácticamente toda la población del planeta, mientras que la caída del Imperio romano, pretensiones universalizadoras eurocentristas aparte, no tuvo tal repercusión global. Asimismo, el año 1945 ha tenido éxito en la historiografía al entenderse como un punto que separa, según la división que habitualmente manejamos en Europa, dos grandes etapas históricas: la historia contemporánea de la denominada historia del mundo actual o historia del tiempo presente. Más concretamente, también es el punto en el que se pasa de una conflagración generalizada a un mundo dividido en dos grandes bloques de poder, y da inicio a una nueva coyuntura histórica mundial conocida como la Guerra Fría.

Este es, grosso modo, el significado histórico que comúnmente se atribuye al año 1945: un año en el que el mundo puso los relojes a cero y comenzó, ex novo, una profunda y amplia reconstrucción. Todo ello, además, me-

\footnotetext{
${ }^{1}$ Focillon escribió: “¿Qué es un año? Astronómicamente, un valor absoluto. Históricamente, ya es otra cosa. Los acontecimientos no se instalan en él con la misma regularidad [...] Su respiración es lenta a veces y a veces jadeante. Tan pronto de ondas cortas como de ondas largas [...] En este sentido, se puede decir que hay años críticos, verdaderos nudos de acontecimientos”. FOCILLON, H.: El año mil. Madrid, Alianza, 1966, pp. 10-12.
} 
diatizado de forma compleja por la lucha de poder que representó la Guerra Fría entre las dos grandes superpotencias. Pero en general se considera que, ciñéndonos a la experiencia de la Europa occidental -y con la notable excepción española-, es el inicio de una época positiva, de reconstrucción, desarrollo y democratización: los años dorados del capitalismo y de la democracia europea. Pero, ¿es ésta una visión acertada? Los avances son indudables, la construcción del estado del bienestar y la mejora de calidad de vida de los europeos también. Asimismo, tras los horrores de la guerra, las sucesivas generaciones de Europa occidental no ha tenido que volver a pasar tan espantosas experiencias -no han tenido la misma suerte personas de otras regiones del mundo, incluyendo zonas de la propia Europa-. Y sin embargo, reconociendo todos estos avances, asistimos en la actualidad a un acelerado desguazamiento de los mismos. ¿Cómo aquello que tantísimo costó alcanzar, con el esfuerzo, o incluso el dolor y la muerte de millones de personas, puede estar siendo revertido con tanta facilidad? ¿Puede ser que la noción de "año cero" -o Stunde null, como dicen los alemanes, representando una destrucción absoluta que Rosellini llevaría magníficamente a la gran pantalla-, ${ }^{2}$ entendido como un momento de borrón y cuenta nueva, haya sido mitificada?; o quizá más probablemente, lo que ocurre es que se trata de una fecha que queda muy lejana en el imaginario colectivo, que nada tiene ya que decirnos hoy en día y de la que nada tenemos que aprender.

El objetivo de este escrito es regresar a 1945, y tratar de comprender las circunstancias y experiencias de los europeos de aquel entonces, para así entender con mayor claridad que la Europa que se construyó después se erigió a partir de las ruinas del Viejo Continente. Intenta, por tanto, ser un breve ensayo contra el olvido de un pasado que, por muy lejano que nos parezca, solo dista 73 años de nuestro presente. ${ }^{3}$ Como apropiadamente apunta la

${ }^{2}$ El largometraje de Roberto Rosellini Alemania, año cero (Germania, anno zero, 1948), retrataba la vida que llevaban los berlineses en las ruinas de la capital prusiana. También expresa este sentir de destrucción y reconstrucción el Gruppe Neubeginnen (Grupo Nuevo Comienzo), integrado por socialdemócratas germanos exiliados en Londres.

${ }^{3}$ En este sentido, Tony Judt recogía con preocupación la situación "de la historia reciente en una época de olvido: la dificultad que al parecer experimentamos para comprender el turbulento siglo que acaba de terminar y aprender de él." JUDT, T.: Sobre el olvidado siglo XX. Madrid, Taurus, 2008, p. 10. 
exposición sobre Auschwitz que recientemente ha visitado Madrid: "No hace mucho. No muy lejos". Para ello se abordan algunos de los rasgos que, posiblemente, mejor representan la situación de la población europea en aquellos momentos: la destrucción de ciudades, arrasadas hasta los cimientos por efecto de los bombardeos; el hambre, acompañada de los abusos asociados a un amplio mercado negro; las tristemente famosas violaciones masivas perpetradas por las tropas soviéticas en su avance hacia el oeste; la traumática liberación de los campos de concentración y exterminio nazis... en fin, el sufrimiento humano extremo de una población que llevaba soportándolo, como poco, desde 1939. Y es que las experiencias formativas vitales de gran parte de las personas europeas durante la primera mitad del siglo XX fueron la guerra, la tortura, la violación, así como hacer frente a la devastación de su mundo.

Para finalizar, en un epígrafe de valoración personal se plantea que la noción de considerar 1945 como una "hora cero" a partir de la que todo cambió está, para Europa occidental, justificada. Pero no debería ser "mitificada" como un punto de inflexión que marcaría un punto de no retorno, asumiendo así que la historia sigue siempre una estela de progreso irreversible- ni, mucho menos, olvidada. Este es, ni más ni menos, el principal objetivo de este trabajo: articular un ejercicio de memoria y reflexión.

\section{5, ¿UN ASUNTO DE CIFRAS?}

En los manuales de historia reciente es un lugar común, al abordar las consecuencias de la Segunda Guerra Mundial, encontrar una sucesión de cifras sencillamente aterradoras: número de muertos (civiles y militares); número de heridos y mutilados de guerra, ciudades arrasadas, número de desplazados... En este epígrafe trabajaremos con algunas de estas cifras, al tiempo que consideramos hasta que punto las meras cifras nos pueden hacer comprender la tragedia; pues corremos quizá el peligro de reducir la experiencia histórica a meras abstracciones numéricas.

Podemos empezar en primer lugar con la destrucción "menos dolorosa", si es que es lícito expresarnos de esta manera. Nos referimos a la destrucción 
material, ya que, como apuntó Hobsbawm: "una vez terminada la guerra fue más fácil la reconstrucción de los edificios que la de las vidas de los seres humanos". ¿Cómo expresar esto? ¿En número de ciudades arrasadas, de edificios devastados, a través de una estimación en unidades monetarias? Toda estimación resultaría en todo punto imposible, tal era el nivel de destrucción. Sólo centrándonos en Alemania, la lista de ciudades reducidas a escombros por los bombarderos sería interminable. Pero es que, además, aun tomando una única ciudad, el nivel de los daños sería de cálculo muy complejo. Por ejemplo, la periodista estadounidense Janet Flanner visitó una arrasada Colonia el 19 de marzo de 1945. Ante las ruinas de la ciudad se solicitó al Departamento Militar estadounidense para la Protección del Arte y de los Monumentos que elaborase un informe. En dicho documento podemos leer:

[...] un $75 \%$ de los edificios de valor histórico-artístico de Colonia ha quedado destruido. El Wallraf-Richartz-Museum, que albergaba las hermosas pinturas de la escuela del sur de Alemania y de Colonia de 1300 a 1550, especialmente los cuadros de Altdorfer, Cranach y Durero, así como la célebre Madonna in Rosenhang de Stefan Lochner, fue alcanzado por una bomba $[\ldots]$ Nuestro experto en arte valora en tan sólo un $10 \%$ los daños sufridos por la Catedral de Colonia [...] La pérdida verdaderamente grave para Colonia y para el mundo son las iglesias románicas del siglo XI, entre ellas sobre todo la Iglesia de los Apóstoles con sus naves laterales del siglo XII, los magníficos mosaicos y la impresionante bóveda de crucero. ${ }^{5}$

¿Cómo se cuantifica semejante nivel de destrucción? Máxime cuando la propia Flanner explicaba inmediatamente después de enunciar el informe que, "comparado con lo que se va encontrando nuestro ejército mientras atraviesa raudo una ciudad tras otra, el panorama ruinoso de Colonia resulta de lo más normal". Esta escena era la habitual en muchas ciudades de Europa, y aquí no insistiremos más en ello, pues posteriormente dedicaremos un epígrafe a la descripción de esta experiencia. Baste, para nuestro objetivo,

\footnotetext{
${ }^{4}$ HOBSBAWM, E.: Historia del siglo XX. Barcelona, Crítica, 2005, p. 51.

${ }^{5}$ Este testimonio de Janet Flanner lo tomo de ENZENSBERGER, H. M.: Europa en ruinas. Relatos de testigos oculares de los años 1944 a 1948. Madrid, Capitán Swing, 2013, pp. 117-118.
} 
insistir en que semejantes niveles de ruina difícilmente pueden sintetizarse en una mera cifra monetaria, por impresionante que esta pueda ser. Corremos el riesgo de enunciar la perogrullada de que el coste de destrucción material en Europa en 1945 probablemente sea infinito o incalculable.

El nivel de destrucción, aunque aquí lo hayamos centrado en el alto valor artístico de los monumentos de Colonia, no se circunscribía sólo a los núcleos urbanos. También afectó al campo y a las infraestructuras de transporte (vías férreas, carreteras, puentes...), complicando la producción y circulación de alimentos; así como a la capacidad industrial. Esto se evidencia a partir del siguiente fragmento:

Yugoslavia perdió el 25 por ciento de sus viñedos, el 50 por ciento de su ganado, el 60 por ciento de vas carreteras del país, el 75 por ciento de sus arados y de sus puentes ferroviarios, una de cada cinco de las viviendas existentes antes de la guerra y una tercera parte de su limitada riqueza industrial, además del 10 por ciento de la población anterior a la guerra. En Polonia, tres cuartas partes de la vía férrea quedó inutilizada y una granja de cada seis cesó su actividad. La mayoría de las localidades y ciudades del país apenas podían funcionar [a lo que podríamos añadir que Varsovia fue totalmente destruida]. ${ }^{6}$

Hay no obstante, cifras que quizá sean más interesantes: el hambre fue una constante entre muchos europeos durante los últimos meses de la guerra. Dejando de lado los casos extremos de los prisioneros de los campos de concentración, condenados muchos de ellos a morir de inanición, tenemos la experiencia holandesa, que motivó la Operación Maná. ${ }^{7}$ Sin embargo, para caracterizar el hambre y comprender mejor que significó, podemos en este caso recurrir a algunos estudios que tratan de calcular la ingesta de calorías diarias en distintas regiones europeas (si bien, aunque nos sirvan para hacer-

\footnotetext{
${ }^{6}$ JUDT, T.: Postguerra: una historia de Europa desde 1945. Madrid, Taurus, 2012, pp. 40-41.

${ }^{7}$ Esta operación fue la operación más importante de socorro de la Segunda Guerra Mundial, tratando de alimentar a la desnutrida población holandesa. En conjunto, "los bombarderos de la RAF realizaron tres mil salidas y lanzaron más de seis mil toneladas de alimentos. Para una infinidad de gente a las puertas de la muerte aquella ayuda supuso la salvación". Los pilotos británicos señalarían que era todo un alivio lanzar alimentos a la población civil, en lugar de bombas. Tomamos esta información de BEEVOR, A.: La Segunda Guerra Mundial. Barcelona, Pasado \& Presente, 2014, pp. 1013-1030.
} 
nos una idea, estas medidas han de ser tomadas con cautela: se trata de medias estimadas, y las desigualdades, los abusos y el funcionamiento de mercados negros podría alterarlas). De este modo sabemos, por ejemplo, que durante gran parte de 1945 la población de Viena subsistió con una ingesta de 800 calorías diarias (muy por debajo de la tasa metabólica basal, que para un adulto de estatura y peso medio se sitúa en torno a unas 1.500 calorías diarias); y que en Budapest, en el invierno de 1945, la ración era de 556 calorías diarias (los niños, en las guarderías, recibían unas 800). En el caso holandés antes aludido, morirían de hambre unas 16.000 personas, en su mayoría ancianos y niños. Otro ejemplo sería la porción alemana ocupada por los estadounidenses, donde la ración diaria oficial para los consumidores alemanes (quedan fuera de este cálculo las categorías favorecidas de trabajadores) se mantuvo en tan sólo 860 calorías. Es decir, en 1945 era tan complicado sobrevivir en la guerra como en la paz, y a la bajada de las defensas por la malnutrición se sumaría la aparición de enfermedades infecciosas, vinculada al elevado número de cadáveres sin enterrar. ${ }^{8}$ Es elocuente que Wachsmann nos informe de que, en los campos de concentración y exterminio nazis, la ración de alimento diaria rondase las 700 calorías. ${ }^{9}$ Aunque, desde luego, la situación dentro y fuera no es comparable: los prisioneros tenían además que enfrentar turnos de trabajo agotadores y todo tipo de vejaciones, por lo que fallecían rápidamente. O todavía de forma más contundente, para tener muy presente que la situación dentro de los Lager era infinitamente peor, las siguientes palabras de Eugen Kogon (prisionero durante seis años en Buchenwald) reflejan la realidad de la subalimentación en los campos nazis: "para juzgar la alimentación en los campos de concentración, no de los datos que figuran sobre el papel, sino de la realidad, obtenemos la siguiente situación: la mayor parte de los prisioneros estaba subalimentada y

${ }^{8}$ Tomamos los datos referentes a las calorías diarias de Judt, quien también nos recuerda el riesgo, asociado a una alimentación insuficiente, de contraer enfermedades infecciosas: "en Berlín, moría un promedio de 10 personas diarias por agotamiento, desnutrición y enfermedad. En la zona británica de Berlín, en diciembre de 1945, la tasa de muertes de niños menores de un año fue de uno de cada cuatro, mientras que durante ese mismo mes se produjeron 1.023 nuevos casos de tifus y 2.193 de difteria”. JUDT, T.: Postguerra..., pp. 46-47.

${ }^{9}$ WACHSMANN, N.: KL. Historia de los campos de concentración nazis. Barcelona, Crítica, 2015, pp. 503-542. 
agotada. Los recién ingresados perdían, en los primeros dos o tres meses, hasta veinte y veinticinco kilogramos de su peso". ${ }^{10}$ Con todo, podemos afirmar rotundamente que el hambre fue también una experiencia muy presente para un importante número de personas en la Europa de 1945.

Pasamos a ocuparnos ya del coste más alto de la guerra: las vidas humanas. Las cifras son directamente aterradoras, y van desde un mínimo de unos 40 millones de personas hasta un máximo de 70, situándose las estimaciones más aceptadas en torno a los 55-60 millones. Es difícil hacerse una idea de tanta muerte sólo a través de estos números. A su lado, el número de muertes ocasionados por la Gran Guerra, aunque terrible, ${ }^{11}$ queda empequeñecido al lado de esta catástrofe. Desagregando estos datos, la peor parte recae sobre la Unión Soviética, con unos 16 millones de civiles muertos aproximadamente el doble de sus bajas militares, lo que nos deja un saldo total de 24 millones de muertos-. Y es que las bajas civiles superaron a las militares en la URSS, Hungría, Polonia (unos cinco millones), Yugoslavia, Grecia, Francia, Holanda, Bélgica y Noruega. "Tan sólo en el Reino Unido y Alemania el número de militares fallecidos superó al de civiles". ${ }^{12}$

Confieso que después de manejar todas estas cifras (aquí sólo ofrecemos una breve selección) uno acaba un tanto mareado. Nos enfrentamos, de esta manera, a una catástrofe humana sin paliativos. Pero, además, es que si tomásemos las estimaciones más bajas, o incluso supusiésemos que el número de muertos fuesen la cuarta, o la quinta, o la décima parte, seguiríamos ante

${ }^{10}$ KOGON, E.: El Estado SS. El sistema de los campos de concentración alemanes. Barcelona, Alba, 2005, p. 165.

${ }^{11}$ Stevenson arroja para la Gran Guerra una cifra muy concreta para las muertes militares: 9.450.000. Para la de civiles muertos se muestra más evasivo, y acaba por apuntar un "déficit total de población", donde se incluyen aquellos bebés que hubiesen sido concebidos de no haberse producido la guerra, que rondaría los 60 millones de personas. STEVENSON, D.: 1914-1918. Historia de la Primera Guerra Mundial. Barcelona, Círculo de lectores, 2013, pp. 69-70. Un cálculo menos abultado lo encontramos en Fontana: "las muertes de civiles se estiman en unos siete millones: un millón como consecuencia de acciones militares directas, y cerca de seis millones por el hambre y las enfermedades causadas por la guerra. Otros elevan esta cifra a diez millones, incluyendo un millón y medio de víctimas del exterminio de los armenios”. FONTANA, J.: El siglo de la Revolución. Una historia del mundo desde 1914. Barcelona, Crítica, 2017, p. 52.

12 JUDT, T.: Postguerra..., p. 40. 
un absoluto desastre. Así lo consideraba también Eric Hobsbawm, que hablaba de estos años como «la era de las catástrofes» y escribía:

[...] ¿qué importancia tiene la exactitud estadística cuando se manejan cifras tan astronómicas? ¿Acaso el horror del holocausto sería menor si los historiadores llegaran a la conclusión de que la guerra (!) no exterminó a 6 millones de personas $[\ldots]$ sino a cinco o incluso a cuatro millones? ¿Qué importancia tiene que en el asedio al que los alemanes sometieron a Leningrado durante 900 días (1941-1944) murieran un millón de personas por efecto del hambre y el agotamiento o tan sólo 750.000 o medio millón de personas? ¿Es posible captar el significado real de las cifras más allá de la realidad que se ofrece a la intuición $?^{13}$

Y lo que nos dice la intuición, o incluso mejor, el sentido común, es que esta fue una catástrofe humana sin parangón. Además, es pertinente centrarse no solo en lo cuantitativo, sino también en las circunstancias en que se produjeron estas muertes: después de salvajes torturas; mujeres violadas y después asesinadas; personas gaseadas con sus hijos después de aguantar el martirio del viaje en tren hasta el infierno de los campos de exterminio en Polonia; pueblos enteros obligados a cavar sus propias fosas comunes y luego asesinados en masa -en lo que Vasili Grossman denominó «Shoa por las balas», antesala del uso del gas como forma "más humana" de exterminio-; la tortura y la muerte en el gulag ruso; la población rusa obligada a enfrentarse, totalmente desarmada y bajo pena de muerte si retrocedían, a los Panzer alemanes; adolescentes berlineses lanzados a la muerte en la defensa de la ciudad porque, en opinión de Hitler, si el pueblo alemán no era capaz de alcanzar la victoria se merecía ser destruido (por no hablar de lo ocurrido en Asia, con las terribles torturas a las que los nipones sometían a sus prisioneros, la destrucción de la población de Nanjing en 1937, o la tristemente célebre Unidad 731). Todo este sufrimiento humano, inconcebible de asimilar, no puede ser reducido a cifras. Los estudio cuantitativos son importantes, absolutamente necesarios, pero intentar comprender las experiencias de todas estas víctimas es una tarea primordial para el historiador.

${ }^{13}$ HOBSBAWM, E.: Historia del..., p. 51. El signo de exclamación es mío: coincido plenamente con la reflexión de Hobsbawm, pero me llama la atención una construcción sintáctica tan impersonal: a los judíos los exterminó «la guerra» y no los nazis y sus simpatizantes. 


\section{“CIUDADES DE LOS MUERTOS": ESCOMBROS, SANGRE Y CENIZAS EN 1945}

La operación Berlín, en la que las tropas soviéticas bombardearon sin descanso la capital alemana, se prolongó desde el 16 de abril hasta el dos de mayo de 1945. Tras la definitiva derrota de la ciudad, y el conocido suicidio de Hitler, Eva Braun y la familia Goebbels al completo, un soldado soviético escribía desde Berlín la siguiente carta a su familia:

Soy incapaz de encontrar palabras hermosas. Todos están borrachos. ¡Banderas, banderas, banderas! Banderas en Unter den Linden, en el Reichstag. Banderas blancas. Todo el mundo cuelga una bandera blanca. Viven entre ruinas. Berlín ha sido crucificada. ${ }^{14}$

Así comienza Antony Beevor un epígrafe significativamente titulado "ciudades de los muertos", que tomamos aquí prestado: escombros y más escombros, y bajo los escombros cadáveres y más cadáveres. Y entre las ruinas, una población exhausta moviéndose como muertos vivientes, tratando de salir adelante cada día. Lo cierto es que cuesta bastante imaginar esta realidad, y cuando uno ve estas imágenes de destrucción es un ejercicio arduo pensar que era un paisaje común en Europa no hace demasiado tiempo: quizá por eso lo mejor sea recurrir a las sensaciones y las palabras de los testigos de aquel escenario.

Como ya hemos abordado previamente, con el caso de Colonia, la destrucción se centró sobre todo en las ciudades alemanas. Ian Buruma nos dice que, "en comparación con Berlín y las demás ciudades alemanas, hasta de Budapest podía decirse que se hallaba en buenas condiciones". Las grandes ciudades -Berlín, Fráncfort, Hamburgo, Bremen, Dresde...- fueron arrasadas hasta los cimientos. Pero incluso otras ciudades menores, "como Würzburg o Pforzheim -destruidas en 1945, cuando poco valor estratégico podían tener-apenas quedaba otra cosa que montones humeantes de escombros que aun hedían a muerte". ${ }^{15}$ Todas estas ruinas dieron lugar, de hecho, a una

\footnotetext{
${ }^{14}$ Este testimonio viene recogido en BEEVOR, A.: La Segunda ..., p. 1061.

${ }^{15}$ Ambas citas proceden de BURUMA, I.: Año Cero. Historia de 1945. Barcelona, Pasado \& Presente, 2014, p. 72.
} 
corriente literaria alemana: la Trümmerliteratur. ${ }^{16}$ En el libro de Buruma también se recoge el testimonio del dramaturgo Carl Zuckmayer al encontrarse en el devastado centro de Berlín:

[...] recordaba cómo había sido aquel mismo lugar antes de la guerra: el ruido incesante del tráfico y las bocinas de los automóviles, y el de las multitudes que charlaban mientras iban de compras, bebían o salían a comer; y no podía menos de sentirse solo entre aquellos cascotes mudos. Oyó un sonido tenue de fricción, y vio a un muchacho delgado de corta edad que, calzado con chancletas de madera, tiraba de un carrito entre los escombros de una calle de adoquines. El viento recorrió suavemente la desolada escena, y Zuckmayer pudo oír el pulso de su propio corazón. ${ }^{17}$

Ya hemos hablado antes de Colonia a través de la voz de Janet Flanner, quien además escribió un 19 de marzo de 1945: "la ciudad de Colonia es en este momento un paradigma de la destrucción [...]lo que ha quedado de su vida se abre camino trabajosamente a través de las calles sepultadas bajo los cascotes: una población disminuida, vestida de negro, y cargada con fardos, taciturna como la ciudad". ${ }^{18}$ Pero la destrucción no era una prerrogativa exclusiva de Alemania, aunque esta se hubiese llevado la peor parte. También hay que tener presente Stalingrado y Leningrado, el efecto de los bombardeos de la Luftwaffe en las ciudades británicas, Nápoles en Italia, la aniquilación de Varsovia a raíz de la revuelta en el gueto judío (y, de nuevo, no olvidarnos de Asia, con Nagasaki e Hiroshima en el primer puesto)... Por ejemplo, sobre la destrucción en Nápoles, uno de los principales testimonios es el del escritor inglés Norman Lewis:

\footnotetext{
${ }^{16}$ La Trümmerliteratur significa literalmente "literatura de los escombros", y se publicó en Alemania después de 1945 describiendo un mundo hecho añicos por la guerra. Algunos de sus representantes más importantes fueron Heinrich Böll, Erich Kästner o Paul Celan. Sin embargo, como apunta Hans Magnus Enzensberger, esta corriente "apenas ha dado frutos más allá de su denominación": como si estos autores quisieran pasar página y dejar atrás un pasado doloroso. La cita de Enzensberger la tomamos de ENZENSBERGER, H. M.: Europa en ruinas..., pp. 15-16.

${ }^{17}$ BURUMA, I.: Año Cero..., p. 72.

${ }^{18}$ Testimonio disponible en ENZENSBERGER, H. M.: Europa en ruinas ..., p. 111.
} 
Es sorprendente ver cómo esta ciudad devastada, hambrienta, despojada de todas sus condiciones de vida, lucha por acomodarse tras el colapso a unas circunstancias que semejan las de la temprana Edad Media. Como beduinos, los napolitanos acampan entre las ruinas. Hay poco que comer, poco agua, no hay sal ni jabón. Muchos napolitanos han perdido en los bombardeos sus posesiones, entre ellas la mayor parte de sus vestidos. ${ }^{19}$

El caso de la destrucción de Varsovia resulta imposible de soslayar, siendo uno de sus aspectos más terribles que los soviéticos rodeasen la ciudad pero no interviniesen hasta estar seguros de que la resistencia polaca, encarnada en el Ejército Nacional, había sido debidamente aplastada. Esto obedecía a una lógica brutal: menoscababa a las fuerzas nazis desplazadas en la ciudad polaca, al tiempo que aseguraba para Stalin el control de Polonia para el futuro. Las intenciones de Stalin sobre Polonia habían quedado ya nítidamente claras en la primavera de 1940, cuando el siniestro NKVD de Lavrenti Beria ejecutó en el bosque de Katyn a "más de 21.000 miembros de la élite polaca, entre ellos mandos militares, profesores y escritores". Del mismo modo, Polonia sería el principal asunto tratado en Yalta: "Stalin estaba dispuesto a admitir unos pocos demócratas simbólicos en su comité de Lublin, dominado por los comunistas. Pero sólo pensaba aceptar un resultado final: la instauración de un gobierno comunista y prosoviético en Polonia". ${ }^{20}$ Un "testigo de los enmudecidos" en la destruida Varsovia es Max Frisch, que un 31 de agosto de 1948 dejaba escritas estas líneas:

Un alto en el casco antiguo: como si fueras el único ser humano sobre la tierra, el último [...] Las malas hierbas en las bóvedas, los escombros, el musgo en los escalones, los charcos, el desmoronamiento, la desintegración, la putrefacción, las fachadas que parecen caretas vacías; no es diferente a Berlín, Múnich, Frankfurt, Hamburgo. Pero esta ciudad fue la primera. Aquí cayeron las bombas decisivas: las primeras, hoy hace nueve años [...] La Historia como conciencia de los vivos. Aquí se ahogó en san-

\footnotetext{
${ }^{19}$ La obra que recoge este testimonio, disponible en castellano, es LEWIS, N.: Nápoles 1994: un oficial del Servicio de Inteligencia en el laberinto italiano. Barcelona, RBA, 2012. No obstante, el fragmento citado procede de ENZENSBERGER, H. M.: Europa en ruinas..., pp. 25-26.

${ }^{20}$ Las dos citas literales son de WALKER, J.: Operación «Impensable». 1945: los planes secretos para una tercera guerra mundial. Barcelona, Crítica, 2015, pp. 23 y 35.
} 
gre y cenizas el desafortunado Levantamiento polaco, aquí se lucha hasta el absurdo, los últimos combatientes se retiran por la canalización, dejan atrás a los heridos, los heridos son alcanzados por las balas. Y ahora uno está aquí con las manos en el bolsillo del pantalón y tiene elección, como en todas partes: ser un testigo de los enmudecidos o enmudecer. ${ }^{21}$

En todos los testimonios recogidos hasta ahora se deja sentir una sensación de desesperación, de incomprensión, de postración total. Y, sin embargo, junto a estos desasosegantes testimonios surgen continuamente otros que nos hablan de vitalidad humana, de una extraña energía que mueve a superar toda dificultad y volver a construir lo destruido. Quizá el mejor testimonio de esta fuerza sea la misiva que Frank Thompson, enviado como enlace británico con la guerrilla yugoslava de Tito, le escribía desde Bulgaria en 1944 a su hermano, el historiador Edward Palmer Thompson:

Hay un espíritu en Europa que es más noble y más valioso que cualquier cosa que este cansado continente haya conocido durante siglos, y que no se podrá detener. Se puede, si se quiere, pensar en ello en términos de política, pero es mucho más amplio y generoso que cualquier dogma. Es la voluntad confiada de pueblos enteros que han conocido los mayores sufrimientos y humillaciones, y que han triunfado sobre ellos para construir su propia vida de una vez y por siempre. ${ }^{22}$

Estos afanes de reconstruir, de empezar de nuevo -o, si se prefiere, de rehacer sus vidas- están presentes en toda Europa. Alfred Döblin, desde el sur de Alemania, nos dice que a sus ciudadanos "la destrucción no les provoca un efecto deprimente sino que les sirve de potente estímulo para ponerse a trabajar. Estoy convencido de ello: si tuvieran los medios que les faltan, mañana gritarían de júbilo, sólo de júbilo porque han destruido sus pueblos viejos, rancios, mal trazados y se les ha dado va posibilidad de poner en pie algo de primera clase acorde a los tiempos". ${ }^{23}$ En Varsovia la actividad febril

\footnotetext{
${ }^{21}$ Este testimonio de Max Frisch está tomado de ENZENSBERGER, H. M.: Europa en ruinas..., p. 375 .

${ }^{22}$ Extraemos el contenido de esta carta de FONTANA, J.: Por el bien del Imperio. Una historia del mundo desde 1945. Barcelona, Pasado \& Presente, 2013, p. 92.

${ }^{23}$ Döblin escribía esto a finales de 1945, y puede encontrarse en ENZENSBERGER, H. M.: Europa en ruinas..., pp. 243-245.
} 
y las ansias de levantar de nuevo la ciudad no eran menores; de ello da cuenta el estadounidense John Gunther, que visitó Varsovia durante el verano de 1948 y dejó constancia de la vitalidad de los varsovianos:

[...] hay otra cosa que me parece más significativa que la terrible destrucción que vimos en Varsovia: el notable éxito de los polacos en la reconstrucción de su ciudad, la energía y el ímpetu de su compromiso, la vida electrizante y chispeante de los ciudadanos. Varsovia es una ruina, pero al mismo tiempo es la ciudad con más vitalidad de Europa [...] Varsovia vive y palpita [...] La gente es pobre, eso no se puede negar; pero renacen de sus cenizas con brío. $\mathrm{Y}$ en esto reside su enorme fuerza moral. ${ }^{24}$

De esta manera, 1945 fue un año en que los europeos hubieron de hacer frente a una crítica situación. Y esto, como resulta lógico, generó en ellos sentimientos contrapuestos: desesperación y apatía, pero también vitalidad y esperanza; miedo e inseguridad, y acompañados sin embargo de confianza en el futuro. Otro sentimiento a tener en cuenta, que en muchos casos se manifestaría de forma sangrienta, sería el afán de venganza. Especialmente en los países ocupados por el Tercer Reich, la liberación trajo consigo la persecución del colaboracionista y del fascista. La violencia engendraba violencia, y algunas voces críticas -siempre necesarias- se pronunciaron en contra de estos actos de venganza. Es oportuno recordar las palabras de Albert Camus en su «Défence de l'Intelligence» en marzo de 1945, donde sostenía: "quizás, la última y más durable victoria del hitlerismo sean esas huellas vergonzosas que han quedado en el corazón de los mismos que los combatieron con todas sus fuerzas [...] Nos ha quedado el odio [...] Al odio de los verdugos ha respondido el odio de las víctimas". ${ }^{25}$ A la misma inteligencia y reflexión apelaba Döblin, que al mismo tiempo que observaba los esfuerzos de las personas por reconstruir sus vidas, constataba con preocupación y pesimismo:

Si uno cree o ha creído en el pasado que la desgracia en su propia tierra y la visión de una devastación tal podría empujar a los seres humanos a la

\footnotetext{
${ }^{24}$ Ibid., p. 363-364.

25 Extracto tomado de la alocución realizada por Camus en la reunión organizada por L'Amitie française el 15 de marzo de 1945.
} 
reflexión y tendría un efecto didáctico en materia de política sobre ellos... puede convencerse: está equivocado. Me muestran determinados conjuntos de edificios y hacen la siguiente constatación: estos fueron destruidos por tal bombardeo y estos por aquel otro, y añaden ciertos episodios. Y eso es todo. No prosiguen con ningún comentario especial, y desde luego no se producen ulteriores reflexiones [...] Será mucho más fácil reconstruir sus ciudades que conseguir que se den cuenta de lo que les ha sucedido y que comprendan cómo sucedió. ${ }^{26}$

Frente a la venganza, aunque evidentemente existió y fue atroz (como ejemplo conocido, el asesinato y posterior desfiguración de los cuerpos de Mussolini y Clara Petacci y otros señalados líderes fascistas en Milán así lo demuestra), la justicia y el derecho también encontraron sus propios cauces de aplicación. Ian Buruma recuerda que -con todas sus imperfecciones- "al menos, en Núremberg se tomaron en serio la ley. El que allí se celebró no fue un juicio rápido propiciado por la ira popular". Y, entre los fiscales jefes del proceso, Robert H. Jackson aseveraría en su alegato preliminar: "el que cuatro grandes naciones, eufóricas por la victoria y heridas por la injuria, hayan optado por refrenar la venganza y someter de manera voluntaria a la justicia del derecho a sus enemigos capturados es uno de los homenajes más significativos que haya rendido jamás el poder a la razón". ${ }^{27}$

\section{MAYO DE 1945: SENTIMIENTOS ENCONTRADOS EN EL DÍA DE LA VICTORIA EN EUROPA}

El 8 de mayo de 1945 el Tercer Reich, finalmente, con Hitler muerto, se rendía de manera incondicional y Europa alcanzaba una paz largo tiempo anhelada. En el imaginario colectivo este es un día de celebración, de euforia y alivio: la guerra había terminado. Las calles de las principales ciudades europeas se llenaron de personas celebrando la paz. Nos son muy conocidas las imágenes de muchedumbres festejando la paz con banderas aliadas, montados sobre carros de combate y bebiendo unos con otros en plena euforia.

\footnotetext{
${ }^{26}$ ENZENSBERGER, H. M.: Europa en ruinas..., pp. 243-245.

${ }^{27}$ Tomo las dos citas de BURUMA, I.: Año Cero..., pp. 245-246.
} 
Esta es una reacción normal y el final de la contienda no exigía menos: fue recibido con una alegría desbordante por la exhausta población europea.

Pero, como hemos visto en el epígrafe anterior, el año 1945 fue un año de gran complejidad, caracterizado por contrarias manifestaciones de ánimo. Para muchas personas, aun reconociendo la importancia del fin del conflicto, el 8 de mayo traía también momentos para la reflexión y para la duda. Unos de estos estados se refleja nítidamente en Simone de Beauvoir, que describe sus recuerdos de aquel día como "mucho más confusos que los que tenía de otros festejos anteriores, quizá por la confusión que reinaba entonces en mis sentimientos. La victoria se había ganado a mucha distancia de nosotros [...] hacía tiempo que se estaba viendo venir, y no ofrecía esperanzas ulteriores. En cierto sentido, aquel final era comparable a la muerte. ${ }^{28}$

También transmite un estado reflexivo Brian Urquhart, un joven oficial del servicio británico que había sido de los primeros en penetrar en el horror de Bergen-Belsen en su liberación. Urquhart, que después llegaría a desempeñar un puesto de subsecretario en Naciones Unidas, se mostraba incapaz de incorporarse plenamente al júbilo generalizado, y sus pensamientos se dirigían al centro de la tragedia. Sobre el 8 de mayo escribía:

No es fácil reconstruir lo que sentí en realidad en aquella ocasión conmovedora. Poco menos de seis años de la desesperación a la victoria; tantos amigos perdidos..., la increíble magnitud de la destrucción... Me preguntaba por todos aquellos rostros sin nombre que aparecían en las fotografías de guerra: refugiados, prisioneros, paisanos bombardeados, soviéticos rodeados de la nieve y las ruinas de su país; la tripulación de cargueros que se iban a pique... ¿Cuántos de ellos iban a volver a ver a sus familias? $?^{29}$

$\mathrm{Y}$ es que esta era una realidad dolorosa para muchas personas en 1945: a todo el mundo le faltaba un familiar, un amante, un amigo. En El dolor, Marguerite Duras escribiría tajantemente: "seis años de guerra terminan. Es la cuestión primordial de este siglo". Pero en esta obra se refleja continuamente la angustia de Duras mientras espera el regreso de su marido, pregun-

\footnotetext{
${ }^{28}$ Las palabras de Simone de Beauvoir proceden de BURUMA, I.: Año Cero..., p. 30.

${ }^{29}$ Ibid., p. 31.
} 
tándose cada día si es posible que pueda seguir vivo entre tanta destrucción. Además de la experiencia de la propia autora, en el libro se recoge la vivencia de Madame Kats, que estuvo seis meses aguardando el regreso de su hija, hasta saber que había muerto en un campo de concentración nazi:

«Toda su ropa está lavada, cosida, planchada. He hecho forrar su abrigo negro, le he hecho poner bolsillos. Todo estaba en una gran maleta con naftalina, lo he ordenado todo, todo está a punto. He hecho poner punteras a sus zapatos y le he cogido los puntos de las medias. Creo que no he olvidado nada». Madame Kats desafía a Dios. ${ }^{30}$

En la URSS, el día "grande" de la celebración no fue tanto el 8 sino el primero de mayo, Día Internacional de los Trabajadores. Stalin quería celebrar este día por todo lo alto y exigió a su comandante Zhúkov que intensificase la ofensiva sobre Berlín. De este modo, en la Unión Soviética se festejó el 1 de mayo de 1945 de manera especial, con salvas de cañones por todas las ciudades importantes. El ruido de los festejos en Moscú llegó hasta la celda número 53 de la Lubianka, donde en esos momentos se encontraba preso Aleksandr Solzhenitsyn. El futuro escritor ruso había sido detenido por haber criticado la forma en que Stalin dirigía la guerra, y había pasado entonces a conocer el mundo de las torturas de la Lubianka. Mientras escuchaba los gritos de júbilo en el exterior, probablemente sabía ya que sería condenado por el artículo 58 del código penal soviético, que implicaba los cargos de "traidor", "saboteador", y "enemigo de los trabajadores". Solzhenitsyn sabía lo que esto significaba: trabajos forzados en cualquier gulag perdido de Siberia y exilio interior. "Así era como se había tratado a los prisioneros políticos en los duros y malos tiempos del zar. En su celda de la Lubianka, Aleksandr Solzhenitsyn empezaba a darse cuenta, poco a poco, de que así se los trataba también en el comunismo". ${ }^{31}$

\footnotetext{
${ }^{30}$ Sendas citas las extraigo de DURAS, M.: El dolor. Barcelona, Alba, 1992, pp. 13 y 65.

31 Tomamos estas líneas referentes a Solzhenitsyn de BEST, N.: Cinco días que estremecieron al mundo. Testigos presenciales del final de la Segunda Guerra Mundial en Europa. Barcelona, Pasado \& Presente, 2014, pp. 219-228.
} 
Este fue el aciago destino para demasiadas personas en la Unión Soviética. De hecho, unos de los aspectos más oscuros que se trató en la conferencia de Yalta - dejando aparte las pretensiones estalinistas sobre Polonia- fue que "Stalin exigió el regreso de cualquier ciudadano soviético que se encontrara en el Oeste al final de la guerra, ya fueran porque eran prisioneros o porque habían huido allí de los comunistas [...] A la postre, su destino sería la ejecución o la vida en uno de los campos de trabajos forzados soviéticos". 32 A muchos de ellos se les aplicaría también el artículo 58; pero incluso a los prisioneros, a los que habían caído prisioneros en manos de los alemanes combatiendo en el Ejército Rojo, se les consideraba peligrosos: seguramente habían sido "infectados" por ideas capitalistas y era necesario que fuesen "reeducados" en el vasto archipiélago gulag estalinista. O, como nos recuerda Jonathan Walker, "mientras Gran Bretaña y Estados Unidos celebraban el Día de la Victoria en Europa, en Polonia no había nada que celebrar. Es más, resulta difícil sobreestimar el sufrimiento y el trauma que había soportado el país durante la ocupación nazi, y que continuó soportando bajo el dominio soviético". ${ }^{33}$ Desde luego, todos estos seres humanos tenían sobrados motivos para sentirse sombríos durante los primeros días de mayo de 1945.

\section{LA TORTURA COMO EXPERIENCIA HABITUAL}

Anteriormente hemos tratado la cuestión de las cifras que se suelen esgrimir al hablar de la Segunda Guerra Mundial, así como sus limitaciones. La tortura, experiencia habitual durante esos años para muchos seres humanos, sería un ejemplo adecuado en relación con este asunto. ¿Cuántas personas fueron torturadas en Europa durante la Segunda Guerra Mundial? Muchas, demasiadas, un número incalculable. Pero incluso aunque consiguiésemos arrojar una cifra, exorbitante sin duda, ¿no estaríamos de nuevo reduciendo todo el horror de esta experiencia a una simple información cuantitativa? Es por ello que consideramos apropiado dedicar un breve apartado a la tortura: desgraciadamente otra experiencia habitual para los europeos de 1945.

\footnotetext{
${ }^{32}$ WALKER, J.: Operación «Impensable»..., p. 37.

${ }^{33}$ WALKER, J.: Operación «Impensable»..., p. 126.
} 
Durante estos años la tortura estuvo muy presente, y ampliamente repartida por toda Europa. Y no sólo en Europa, por supuesto, en los gulag de la Unión Soviética era también un elemento central; ${ }^{34}$ y mención aparte merecen los militares japoneses, practicando la vivisección sin anestesia sobre seres humanos en los laboratorios de la Unidad 731 en Manchuria. Asimismo, los nipones tenían un método de tortura tan simple como atroz: obligaban a una persona a beber agua hasta reventar, y después, boca arriba y con los brazos y piernas extendidos, saltaban sobre su estómago una y otra vez. No obstante, al centrarnos en Europa en este trabajo, y dada la limitación de espacio, lo apropiado parece centrarse en los mayores torturadores de esta región durante la Segunda Guerra Mundial: las SS y la Gestapo. Y es que, como apuntan algunos de los que la sufrieron en sus manos, "la tortura no fue un elemento accidental, sino la esencia del Tercer Reich". ${ }^{35}$ Podemos considerar la tortura como una de las más terribles expresiones del terror y la violencia: en este sentido, el nazismo destacaba al crear un clima de terror basado, no sólo en la humillación, la tortura y el asesinato, sino en gran medida en la arbitrariedad. Los castigos represalias y vejaciones en muchas ocasiones se llevaban a cabo al azar, sin ninguna razón aparente. También, por supuesto, los torturadores nazis buscaban con ello obtener información por ejemplo de los miembros de las distintas resistencias-, pero esto no minusvaloraría el papel de control y opresión social a través de un terror ejercido arbitrariamente.

Desde luego, donde era más habitual la tortura era en los campos y en las siniestras mazmorras gestionadas por las SS y la Gestapo - de infausto recuerdo, por ejemplo, serían la Rue Lauriston parisina, donde oficiaba la Gestapo francesa de Bonny y Lafont; o Fort Breendonk en Bélgica-.

${ }^{34}$ Arthur Koestler, aunque no la sufrió él mismo, relata la tortura en la URSS a través de Rubashov en los siguientes términos: "Rubashov se quedó inmóvil, de pie entre el camastro y el balde, conteniendo la respiración y esperando el primer grito. Recordaba que ese primer grito de dolor, en el que el terror todavía predominaba sobre el daño físico, era generalmente el peor; lo que seguía era ya más soportable, porque uno se acostumbraba a ello, y después de cierto tiempo se llega incluso a deducir el método de tortura por el tono y ritmo de los alaridos.” KOESTLER, A.: El cero y el infinito. Buenos Aires, Emecé, 1960, p. 18.

${ }^{35}$ AMÉRY, J.: Más allá de la culpa y la expiación. Tentativas de superación de una víctima de la violencia. Valencia, Pre-textos, 2001, p. 119. 
Aquí la arbitrariedad a la hora de castigar y torturar alcanzaba sus más elevadas cotas. Así lo explicaba Eugen Kogon: "sobre la medida del castigo que podía imponer la SS no existían [...] normas fijas. Dependía del humor y la arbitrariedad de la SS, incluso cuando se trataba de castigos contra todo el campo, mejor dicho: especialmente en tales casos" ${ }^{36} \mathrm{La}$ escritora estadounidense Martha Gellhorn estuvo presente en la liberación de Dachau, y refiere que allí conoció a un cirujano polaco con "tan sólo cuatro de sus dientes delanteros ya que los demás, a ambos lados, se los había extraído un día un guardia simplemente porque le habían entrado ganas de arranciar dientes. Aquel acto no parecía constituir un motivo de asombro ni para el médico ni para los demás". 37

Gellhorn también estuvo presente en la liberación de París, ciudad que se libró de la devastación de los bombardeos, pero que quedaría sacudida en lo más hondo por las torturas allí perpetradas por el nazismo. Las heridas de París no se traducen en una inconcebible destrucción material, sino en la destrucción humana a través de las torturas. La autora nos habla de los túneles subterráneos de Ivry, una de las más antiguas fortificaciones de París. A los alemanes les pareció buena idea emplear estos agujeros como cárcel, de tal modo que "en esta oscuridad húmeda e infinita, encerraron a hombres y mujeres hasta que murieron o hasta que les tocó morir torturados o fusilados". También hace referencia a Romainville, otra fortaleza francesa que fue empleada como lugar de tortura. En concreto, en un pequeño barracón había un cajón en el que se alcanzaban grandes temperaturas, con unos ganchos sobre el mismo para tender y secar ropas, mantas... Pero los alemanes pensaron que era una buena idea meter personas allí dentro y cocerlas vivas:

Hasta que una persona moría en ese cajón cerrado, revestido de metal, se necesitaba algún tiempo. Primero se abrasaban los pies y cuando uno se estira hacía arriba en su suplicio, se agarra a los ganchos que están al rojo vivo. Quien no puede estar de pie se ve obligado a apoyarse en las paredes candentes del cajón. Y si hay alguien que después de todo esto aún sigue

\footnotetext{
${ }^{36}$ KOGON, E.: El Estado SS..., p. 160.

${ }^{37}$ Testimonio tomado de ENZENSBERGER, H. M.: Europa en ruinas..., p. 158.
} 
con vida, lo sacan, lo atienden, lo interrogan y si se niega a confesar lo vuelven a meter en el cajón. ${ }^{38}$

Este es un tema siempre difícil de tratar: la experiencia de la tortura siempre es algo deshumanizador y, por tanto, execrable: nos afecta profundamente abordar su estudio. Resulta imposible concebir el terror y el dolor que han sufrido las personas que han padecido tortura. En Francia, para los miembros de la resistencia, la secuencia solía ser golpes con porra, rotura de articulaciones, ahogamiento en agua helada, arrancar las uñas, colgamiento de una cuerda con las manos a la espalda, impedimento del sueño, descargas eléctricas... Marc Bloch pasó por ello, y luego fue ejecutado; así como Jean Moulin, quien afrontó heroicamente sin decir una palabra las torturas de Klaus Barbie; Stéphane Hessel, que pasó por Buchenwald y Dora-Mittelbau, también, aunque salió vivo para contarlo después de haber sido detenido a raíz de una delación. El delator había sido previamente torturado, y Hessel apunta: "espero al menos que al entregarme consiguiera su propia libertad. Nunca lo he sabido. No se puede perseguir a alguien que ha hablado bajo tortura". ${ }^{39}$

Jean Améry también fue torturado y, veintidós años después de aquello, seguiría afirmando "que la tortura es el acontecimiento más atroz que un ser humano puede conservar en su interior"; al tiempo que constituye la aniquilación total del derecho a la dignidad humana y la inversión del mundo social. ${ }^{40}$ Jorge Semprún, prisionero en Buchenwald, señalo que sufrir la tortura sólo es soportable si el ser humano trasciende de sí mismo y se agarra, con todas sus fuerzas, al ideal de la solidaridad y la fraternidad humana universales:

[...] la experiencia de la tortura no es únicamente, quizá ni siquiera principalmente, la del sufrimiento, la de la abominable soledad del sufrimiento. Es también, sobre todo sin duda, la de la fraternidad. El silencio al

\footnotetext{
${ }^{38}$ Las dos citas en Ibid., pp. 55-62.

${ }^{39}$ HESSEL, S.: Mi baile con el siglo. Memorias. Barcelona, Destino, 2011, p. 121.

${ }^{40}$ La cita literal está tomada de AMÉRY, J.: Más allá de la culpa ..., p. 116. Sobre la "inversión del mundo social", en las páginas 146-147 podemos leer: "la tortura supone una inversión absoluta del mundo social: en éste podemos vivir sólo si reconocemos la vida también al prójimo, si dominamos el impulso expansivo del yo, si mitigamos su sufrimiento. Pero en el mundo de la tortura, el hombre subsiste sólo en la destrucción del otro".
} 
que uno se aferra, contra el que uno se apoya apretando los dientes, intentando evadirse mediante la imaginación o la memoria de su propio cuerpo, su miserable cuerpo, ese silencio es rico en todas las voces, todas las vidas que protege, a las que permite seguir existiendo. Y sin duda el ser del resistente torturado se convierte en un ser-para-la-muerte, pero es también un ser abierto al mundo, proyectado hacia los demás: un ser-con, cuya muerte individual, eventual, probable, alimenta la vida [...] Es una experiencia de solidaridad a la par que de soledad. Una experiencia de fraternidad, no hay palabra más apropiada. ${ }^{41}$

Estas palabras, francamente impresionantes, nos hacen pensar que en una etapa marcada por el sufrimiento humano extremo, también había espacio para los más elevados valores a los que podemos aspirar: generosidad, entrega, amor, empatía... "fraternidad, no hay palabra más apropiada". Este es el legado que nos dejaron en 1945 todas aquellos hombres y mujeres que lucharon por la libertad y por la dignidad humana $-\mathrm{y}$ que fueron torturados por ello-. Porque, para poner fin a este apartado, esta es la identidad a la que nunca deberíamos renunciar: la humanidad. En la tortura, la víctima puede ser cosificada, pero el que realmente se envilece y se deshumaniza no es otro que el torturador. Francisco Tomás y Valiente lo expresó a la perfección:

La mayor vileza imaginable es la tortura, porque consiste en la negación del hombre como ser que vale por sí mismo, sea quien sea, e implica su sustitución por un instrumento sufriente que sólo sirve para contestar y padecer $[\ldots]$ La tortura degrada, humilla y destruye. El torturador se degrada porque su absoluta falta de respeto a la víctima se vuelve contra él y lo deshumaniza. El horrendo espectáculo de la tortura apenas tiene algo de humano, porque el hombre que es víctima ha sido convertido en cosa por los administradores de su dolor, y éstos se transforman en seres diabólicos que fueron hombres antes de perder su dignidad. Solo es humano el sufrimiento del torturado, humillado y ofendido. ${ }^{42}$

\footnotetext{
${ }^{41}$ SEMPRÚN, J.: Ejercicios de supervivencia. Barcelona, Tusquets, 2016, pp. 58-60.

42 Esta cita pertenece al artículo "Sobre la tortura y otros males menores", publicado el 3 de abril de 1995 en El País tras ser identificados los cadáveres de los torturados y asesinados etarras Lasa y Zabala. Se puede consultar en TOMÁS Y VALIENTE, F.: A orillas del Estado. Madrid, Taurus, 1996, pp. 73-78.
} 


\section{LA VIOLACIÓN COMO INSTRUMENTO DE TERROR: EL AVANCE DEL EJÉRCITO ROJO}

La corresponsal de guerra soviética Natalya Gesse escribió mientras acompañaba al Ejército Rojo en su avance hacia el este: "los soldados rusos violaban a todas las mujeres alemanas entre los ocho y los ochenta años [...] era un ejército de violadores. No sólo porque estaban locos de lujuria, sino porque aquello constituía una especie de venganza". ${ }^{43} \mathrm{Y}$ aunque Beevor considere ésta una generalización excesiva, y recuerde que hubo muchos oficiales y soldados que no tomaron parte en las violaciones y que se sintieron horrorizados ante las mismas, en su monografía sobre la caída de Berlín afirma tajantemente: "El destino más extendido de toda mujer y niña, independientemente de su edad, era ser víctima de las violaciones colectivas". La explicación de estas violaciones a partir de la venganza tampoco acaba de convencer: parece más apropiado considerarlo, de nuevo, como un bestial proceso de deshumanización de aquel que es considerado como un enemigo a destruir -en este caso: las enemigas, es decir, cualquier mujer alemana- ${ }^{44}$

Asimismo, si en el epígrafe anterior hemos sostenido que, para el nazismo, la tortura no era sólo un método de obtener confesiones, sino un mecanismo estructural para mantener su sistema de violencia y terror, otro tanto se puede decir aquí de las masivas violaciones llevadas a cabo por los soldados soviéticos. Como la tortura institucionalizada, estas violaciones, llevadas a cabo de manera sistemática contra toda mujer alemana -la edad era, como hemos visto, algo indiferente- no era otra cosa que un devastador instrumento de terror asociado al género.

Quizá uno de los aspectos más truculentos sea que la propia oficialidad del Ejército Rojo animaba a sus soldado a violar a cuántas más mujeres mejor. Esto fue especialmente grave dentro de unos cuerpos militares soviéticos conocidos como las compañías shtraf (que en ruso vendría a significar “compañía de castigo"). Sus integrantes, los shtrafniks, eran en su mayor parte criminales reincidentes venidos de los gulag. La crueldad de estos delincuentes, y la indiferencia hacia sus víctimas, estaba también presente entre

\footnotetext{
${ }^{43}$ Obtengo este testimonio de BEEVOR, A.: La Segunda ..., p. 955.

${ }^{44}$ BEEVOR, A.: Berlín. La caída: 1945. Barcelona, Crítica, 2002, p. 45.
} 
sus oficiales; por ejemplo, un oficial médico de una compañía shtraf dejaría escrito lo siguiente:

[...] nuestra compañía se lo pasaba bien. Una joven alemana vino corriendo hacia mí en Halsberg y me dijo gritando en alemán: «¡He sido violada por catorce hombres!». Yo seguí caminando mientras pensaba: «es una lástima que hayan sido catorce y no veintiocho. Es una lástima que no te hayan pegado un tiro, perra alemana». Los oficiales de la compañía shtraf cerramos los ojos ante todas las cosas, no tenemos compasión de los alemanes y dejamos que los shtrafniks hagan a los civiles lo que quieran. ${ }^{45}$

Abundan testimonios tan estremecedores como éste, no sólo en Berlín, sino en cualquier región de Alemania. Uno de los más vergonzosos se produjo en Goldap, localidad polaca próxima a Prusia oriental. Tal y como describe Leonid Rabichev -escandalizado y asqueado por el comportamiento de sus camaradas-, un teniente radiotelegrafista del XXXI Ejército, las tropas rusas alcanzaron en la carretera a una caravana compuesta por mujeres, ancianos y niños alemanes que huían hacía el oeste. Rápidamente los soviéticos iniciaron una violación masiva de estas mujeres entre risas, bramidos y burlas, mientras "el comandante mataba a tiros a los niños y ancianos, que estaban histéricos". ${ }^{46}$ No hay palabras para calificar tanta barbarie: desgraciadamente, la violación más cruel, muchas veces seguida del asesinato, también fue una experiencia común para las mujeres europeas en 1945.

\section{5: EL MUNDO CONOCE EL HORROR DEL GENOCIDIO NAZI}

El 11 de abril de 1945 las fuerzas aliadas entraban en Buchenwald, atravesando una puerta presidida por el infame letrero Jedem das Seine; a mediados de ese mes descubrían el campo de concentración de Bergen-Belsen; el 29 de abril liberaban Dachau; el 5 de mayo Mauthausen... Lo que allí se encontraban es de sobra conocido: un dantesco escenario de muerte y degradación humana. Marguerite Duras dejaría escrito, refiriéndose al antes de

\footnotetext{
${ }^{45}$ Obtengo este testimonio de BEEVOR, A.: La Segunda ..., p. 956.

${ }^{46}$ Ibid., p. 953-954.
} 
estos horrorosos descubrimientos: "estamos en los albores de la Humanidad, una Humanidad virgen, virginal [...] Nada había sido revelado todavía sobre la Especie Humana". ${ }^{47}$ De hecho, la propia Duras recuperaría de este horror a su marido: un varón de 178 centímetros de altura que regresó de Dachau pesando 38 kilos. Martha Gellhorn estuvo en la liberación de este campo, y refiere que "en ningún otro lugar ha existido algo como esto. En ninguna guerra ha habido nunca algo tan terriblemente brutal como estos muertos famélicos y maltratados, desnudos y anónimos". Un soldado estadounidense dijo: "nadie nos creerá", a lo que otro, visiblemente afectado, exclamaba una y otra vez: "tenemos que hablar de todo esto. Tenemos que hablar de ello tanto si nos creen como si no". ${ }^{48}$ Su pretensión bien podía basarse en la idea de que aquello tenía que saberse, para que jamás volviese a ocurrir. La misma idea estaba presente en Buchenwald, donde de inmediato las letras de hierro forjado que contenían la sentencia Jedem das Seine ("a cada uno lo suyo") fueron tapadas con un letrero que rezaba: «¡Nunca más!».

En Buchenwald estaba Eisenhower, quien quedó tan horrorizado que ordenó que corresponsales de guerra lo registrasen todo, y que los vecinos de las localidades adyacentes al campo lo visitaran de inmediato. En Belsen, unos treinta mil prisioneros se hallaban en una especie de limbo entre la vida y la muerte, rodeados de más de diez mil cadáveres en estado de putrefacción. El campo había visto aumentar exageradamente su población con la llegada de los supervivientes de las marchas de la muerte. El oficial de mayor rango allí determinó que se trajese de las inmediaciones a todos los habitantes alemanes a punta de bayoneta: "cuando se les obligó a trasladar los cadáveres a las fosas comunes, estos civiles alemanes quedaron espeluznados y declararon que no sabían nada de todo aquello, lo que enfureció aún más a los oficiales británicos, que no creyeron sus palabras". ${ }^{49}$ Estas imágenes dieron la vuelta al mundo, causando un estupor generalizado. Conviene no olvidar que este horror, por encima de todo este horror, constituye el legado del Tercer Reich.

\footnotetext{
${ }^{47}$ DURAS, M.: El dolor..., p. 140.

48 Testimonio de Martha Gellhorn en Dachau, disponible en ENZENSBERGER, H. M.: Europa en ruinas..., pp. 155-163.

${ }^{49}$ BEEVOR, A.: La Segunda ..., p. 1027.
} 
Este mecanismo de tortura y asesinato sistematizados que fueron los campos de concentración y exterminio están presentes desde el principio del régimen hitleriano -Dachau precisamente sería el primer campo, abierto ya en 1933-. Su seña de identidad es la violencia, y en estos lugares la violencia y la crueldad alcanzaron cotas inimaginables. En ellos se llevó a cabo la fase final del Holocausto, la aniquilación física que un grupo de altos cargos nazis en Wansee planeó concienzudamente. Pero, como nos recuerda Grossman, ya antes de Wansee se llevaría a cabo la "Shoa por las balas", ejecutada en la retaguardia del avance alemán por los Einsatzgruppen y la Ordnungspolizei. En 1941 se producirían los despiadados asesinatos de Babi Yar, a las afueras de Kiev, siendo ejecutados más de 30.000 judíos en una sola operación. Comunidades enteras eran obligadas a cavar sus propias tumbas, $\mathrm{y}$ después eran desnudados, fusilados con sus bebés en brazos, y enterrados (en muchos casos, todavía vivos). El propio Heinrich Himmler asistió a una de estas ejecuciones, especialmente preparada para él, en Minsk: no pudo resistir el horroroso espectáculo, y por ello dictaminó que había que encontrar un método de aniquilamiento que fuese más "humano" para los verdugos. Se probaría con dióxido de carbono, explosivos... y el tres de septiembre de 1941 se gasearía por primera vez con Zyklon B a prisioneros soviéticos y polacos. Se producía de esta manera el tránsito de la "Shoa por las balas" a la "Shoa por el gas".

El horror alcanzó dimensiones grotescas en los campos de exterminio del este, todos ubicados en Polonia. En este caso, los nazis los desmantelaron en 1944 y trataron de borrar toda prueba de su existencia: dinamitaron las cámaras de gas; desmantelaron los barracones; o incluso se llevaron, raíl a raíl, las vías férreas que culminaban en la entrada de estas fábricas de la muerte. Pero el crimen era de tal magnitud que cualquier intento de esconderlo fue vano. En Treblinka estuvo Vasili Grossman, quien se pregunta sobre si realmente los nazis pensaron que era posible ocultar lo que habían hecho:

La tierra arroja a la superficie esquirlas de huesos, dientes, objetos diversos y papeles: se resiste a guardar todos esos secretos [...] Y hay más. Más cosas que parecen empujadas a la superficie desde esta tierra insondable, como si alguna mano anónima sacara a la luz tantas cosas sepultadas por los alemanes $[\ldots]$ más adelante, hay más y más cabellos. Por lo visto, 
se trata del contenido desperdigado de uno solo de los sacos de cabellos que salían del campo. Todo es cierto. La última esperanza de que fuera un sueño se desvanece de golpe. [...] Y uno siente que el corazón, aplastado por una tristeza, por un dolor y por una pena que superan lo que le es dable soportar a un hombre, dejará de latir de repente. ${ }^{50}$

Prisionero y testigo de Auschwitz fue Primo Levi, quien ha dejado narrado como en estos lugares al ser humano se le despojaba de toda dignidad y de cualquier valor o consideración: sólo quedaba una bestial lucha por una supervivencia que fue negada a la gran mayoría de los prisioneros: "quiero invitar ahora al lector a que reflexione sobre lo que podría significar en el Lager nuestras palabras «bien» y «mal», «justo» e «injusto»; que juzgue [...] cuánto de nuestro mundo moral podría subsistir más allá de la alambrada de púas" ${ }^{51}$ Es preciso insistir: este es el legado del nazismo; ocurrió en Europa y ocurrió hace no mucho tiempo, y no podemos permitirnos olvidarlo ni restarle gravedad.

Con todo, los nazis pretendieron acabar con la humanidad de sus víctimas pero no pudieron hacerlo. Muchos supervivientes demostraron una fortaleza sin igual $\mathrm{y}$, después de atravesar tan traumáticas vivencias, seguían siendo capaces de amar y de reconstruir su vida. En Belsen, la misteriosa llegada de una caja repleta de pintalabios pone de manifiesto como las prisioneras, con sólo recuperar el contacto con simples objetos de la vida cotidiana, recuperaban rápidamente su humanidad. Contamos con el testimonio al respecto del teniente coronel Gonin: "creo que no hubo nada que hiciera un bien mayor a las internas que aquél carmín [...] volvió a convertirlas en seres individuales, volvían a ser alguien, y no sólo un número tatuado en el brazo. Por fin podían prestar cierto interés a su aspecto externo. Aquellos pintalabios comenzaron a devolverles su humanidad". ${ }^{52}$ Una de las expresiones más evidentes de esta recuperación fue, tal y como nos cuenta Ian Buruma, la recuperación de la actividad

\footnotetext{
${ }^{50}$ GROSSMAN, V.; EHRENBURG, I.: El libro negro. Barcelona, Galaxia Gutenberg, 2011. También se puede consultar GROSSMAN, V.: El infierno de Treblinka. Barcelona, Galaxia Gutenberg, 2014.

${ }^{51}$ LEVI, P.: Trilogía de Auschwitz. Barcelona, Península, 2015, p. 116.

52 Tomado de BURUMA, I.: Año Cero..., p. 41.
} 
sexual y el número de embarazos, como si los supervivientes quisiesen engendrar vida allí donde sólo había existido muerte:

Los antiguos campos de concentración [...] en los que habían muerto tantos miles de personas en las peores condiciones imaginables, se habían trocado en lugares de febril actividad sexual, como si los supervivientes estuviesen ansiosos por demostrarse y demostrar al mundo que seguían con vida y que, además, eran perfectamente capaces de engendrar vida. ${ }^{53}$

\section{DESTERRADOS Y DESARRAIGADOS EN 1945}

En 1945, el caos generado por los nazis en Europa, unido al avance soviético hacia el oeste y las ulteriores modificaciones fronterizas, dieron lugar a cientos de miles de desplazados. El corresponsal de guerra australiano Godfrey Blunden diría: "hoy por las calles de Alemania está toda la historia de Europa, o mejor dicho, del mundo". ${ }^{44}$ Muchos de ellos trataban a regresar a unos hogares de los que ya no quedaba nada. Huían de lugares donde la población local los despreciaba y, cuando llegaban a sus lugares de procedencia, tampoco eran bien recibidos debido a la escasez de alimento, de viviendas y, en fin, de cualquier medio para hacer frente a la desastrosa situación. William Byford-Jones, un oficial del ejército británico. Describió así la situación en 1945:

¡Desechos humanos! Mujeres que habían perdido a sus maridos e hijos, hombres que habían perdido a sus mujeres; hombres y mujeres que habían perdido sus hogares y a sus hijos; familias que habían perdido enormes granjas y fincas, tiendas, destilerías, fábricas, molinos, mansiones. También había niños pequeños que vagaban solos, cargando con un hatillo, llevando una patética etiqueta pegada. Sus madres habían sido separadas de ellos por algún motivo, o bien habían muerto y habían sido enterradas por otras personas desplazadas en algún punto al borde del camino. ${ }^{55}$

\footnotetext{
${ }^{53}$ BURUMA, I.: Año Cero..., p. 42.

${ }^{54}$ Extraigo esta información de BEEVOR, A.: La Segunda ...,p.1068.

55 JUDT, T.: Postguerra..., pp. 48-49.
} 
Gran parte de este desastre, está claro, obedecía a la expansión de Hitler y a sus políticas de exterminio y repoblación con alemanes "puros". Pero al final de la guerra los proyectos estalinistas sobre Polonia iban a contribuir a agrandar el problema. Además, conviene no olvidar que la Carta del Atlántico, suscrita entre Churchill y Roosevelt el 14 de agosto de 1941, acordaba la no modificación de fronteras sin el consentimiento de aquella comunidad humana que se viese afectada. Pero en Moscú, en 1944, el propio Churchill pasaría a Stalin una nota en la que las ya más que probables potencias vencedoras comenzaban a repartirse el destino de millones de europeos. ${ }^{56}$ Desde luego, el poderío mundial del Reino Unido se había terminado, y las dos potencias que ahora contaban eran Estados Unidos y la Unión soviética. Y Stalin estaba firmemente determinado a engullir Polonia: las autoridades soviéticas orquestaron una serie de intercambios de población entre Ucrania y Polonia, de tal modo que un millón de polacos fueron expulsados de sus casas, mientras que medio millón de ucranianos partieron para la Unión Soviética entre 1944 y 1946.

$\mathrm{Y}$ así podríamos seguir enumerando -el regreso a casa de toda suerte de deportados; croatas huyendo de la ira de los partisanos de Tito; voluntarios de las Waffen SS procedentes de Noruega (éstos, además, cometerían mil tropelías allí por donde pasaban); huida de alemanes de Prusia oriental; soldados soviéticos obligados a regresar a su tierra (donde les esperaba en muchos casos un centro de "reeducación")... La lista es demasiado larga: la deportación, el desarraigo, y el sufrimiento unido a ellos fueron también una experiencia frecuente para los europeos en 1945 (y fuera de Europa, en esos años, también). Para terminar, y por realizar un breve ejercicio comparativo, entre 1914 y 1922 se estima que hubo entre cuatro y cinco millones de refugiados. Para ellos se creó el pasaporte Nansen, homenajeando al célebre

\footnotetext{
${ }^{56}$ En la nota, conocida como "documento escabroso" se establecía el reparto, en términos de porcentaje, de Rumanía, Grecia, Yugoslavia, Hungría y Bulgaria. Jonatham Walker apunta que "lo que parece un documento cínico era en realidad la reacción de Churchill a unas noticias repentinas. Había oído, a través de ULTRA, que los alemanes estaban a punto de evacuar Atenas y que existía el riesgo inmediato de que el vacío se llenara de partisanos comunistas. Estaba dispuesto a sacrificar una Rumanía ya dominada por los soviéticos para tener carta blanca en Grecia". WALKER, J.: Operación 《 Impensable $\gg$..., p. 30.
} 
explorador noruego del Ártico -su correlato sería la IRO (International Refugee Organization), creada en 1946 en el seno de Naciones Unidas-. Pero estas cifras se quedan muy pequeñas comparadas con el exilio masivo que representó la Segunda Guerra Mundial: en palabras de Hobsbawm:

[...] esa primera oleada de desterrados humanos no fue nada en comparación con la que se produjo en la Segunda Guerra Mundial o con la inhumanidad que fueron tratados. Se ha estimado que en mayo de 1945 había en Europa 40,5 millones de desarraigados, sin contar con los trabajadores forzosos no alemanes y los alemanes que huían ante el avance de los ejércitos soviéticos [...] En suma, la catástrofe humana que desencadenó la Segunda Guerra Mundial es casi con toda seguridad la mayor de la historia. ${ }^{57}$

\section{ELEGIR EN 1945: «QUIEN SALVA UNA VIDA, SALVA AL MUNDO ENTERO»»}

Más arriba hemos visto como Max Frisch, en la destruida Varsovia de 1945, decía que el ser humano siempre tiene elección, y él entonces elegía ser la voz de los enmudecidos. Por supuesto, la posibilidad de elegir o no en la vida es algo que no debería analizarse en términos teóricos: uno se enfrenta a las disyuntivas condicionado por unas circunstancias concretas. Y en 1945 esas circunstancias eran muy difíciles, elegir era complicado. Las víctimas nunca pudieron elegir; pero fuera de las víctimas, otras personas sí lo hicieron, y demostraron que en medio del horror siempre se puede hacer el bien. Analizamos aquí algunos de estos casos -somos conscientes de que hay muchos otros-, bien conocidos, pero que deben ser recordados por su elevado nivel de humanidad. Empecemos por dos jóvenes, ambos imbuidos de profundas convicciones religiosas, uno alemán y otro polaco, que después llegarían a alcanzar el pontificado. ${ }^{58}$

El recluta Joseph Ratzinger se había mostrado contrario a la guerra desde el primer día: procedía de una familia de católicos devotos y su padre, ferviente antinazi, nunca había querido tener nada que ver con el militarismo

\footnotetext{
${ }^{57}$ HOBSBAWM, E.: Historia del..., pp. 59-60.

58 Tomo las citas que vienen a continuación, sobre Ratzinger y Wojtyla, de BEST, N.: Cinco dias..., pp. 241-256 y 200-312.
} 
alemán. Nicholas Best refiere que Ratzinger se alegró al tener noticias del desembarco de Normandía: aquello podía poner fin rápidamente a tanto sufrimiento. A finales de 1944, con Hitler obligando ya al pueblo alemán a autoinmolarse, las SS llevaron a cabo una tarea de "reclutamiento" en la que cogían a un grupo de jóvenes y les presionaban para que se alistasen voluntarios. Ratzinger estaba entre ellos; tenía entonces diecisiete años:

[...] las SS hicieron una sesión de reclutamiento en la que sacaron a los jóvenes de la cama, los alinearon y, ante toda la presión del grupo, los instaron a presentarse voluntarios. Un buen número cedió, con demasiado sueño o falta de carácter para negarse. Ratzinger, en cambio, los rechazó y alegó que, cuando acabara la guerra, sería sacerdote católico. Los hombres de las SS se burlaron de él y le hicieron salir de la estancia entre el abucheo general. A Ratzinger no le importó. Había visto trabajadores esclavos de Dachau y el transporte de los judíos húngaros a la muerte. No quería formar parte de las SS.

Nuestro segundo personaje es, obviamente, Karol Wojtyla, que tenía 19 años el día que estalló el conflicto. Estudiante en la Universidad Jaguelónica, tuvo que interrumpir sus estudios ese mismo año de 1939, cuando Cracovia cayó y la universidad cerró sus puertas: muchos de sus trabajadores y profesores acabarían en campos de concentración. No obstante, Wojtyla continuó sus estudios de manera clandestina durante la ocupación nazi, y contribuyó a ayudar y salvar la vida a los judíos polacos. Se hizo una pregunta que, seguramente, muchos católicos se hicieron en esos años: ¿cómo era posible que desde Roma no hubiese ninguna condena, ninguna queja, ante tanto sufrimiento humano?

Wojtyla ayudó a otros hombres, a su vez, ocultando a varios judíos de los alemanes, consiguiéndoles nuevas identidades y proporcionándoles partidas de bautismo con las que demostrar que eran cristianos. Su mentor, el arzobispo Sapieha, había presentado súplicas reiteradas al Papa en nombre de los judíos polacos, pero el Vaticano no ofreció ninguna respuesta destacable. Wojtyla se preguntaba qué clase de Papa había en Roma, que se cruzaba de brazos y no hacía nada mientras los judíos sufrían por toda Europa. Aquello no era lo que él entendía por caridad cristiana. 
El tercer caso es seguramente el más conocido debido a la película de Steven Spielberg, estrenada en 1993, La lista de Schindler. Oskar Schindler fue un industrial alemán que dirigía una fábrica en la región de los Sudetes checos. En ella había dado cobijo a más de mil judíos huidos de Cracovia, incluidas sus esposas e hijos. Schindler los salvó de una muerte segura al inscribir sus nombres en una lista e insistir a los nazis que se trataba de obreros especializados, imprescindibles para el esfuerzo de guerra. Para convencerlos, además, tuvo que gastarse su fortuna personal en sobornos. Tras el suicidio de Hitler, Schindler temía que las SS asesinasen a sus trabajadores, y por ello les había proporcionado armas con las que defenderse de tal eventualidad. Ante el avance de los rusos, Schindler hubo de abandonar Checoslovaquia, pues un industrial alemán no podía esperar un trato muy favorable por parte de los soviéticos. Era muy reticente a hacerlo, pero sus trabajadores insistieron inflexiblemente al tiempo que le preparaban un regalo de despedida:

A espaldas de Schindler [...] sacrificaron dientes de oro para hacerle un pequeño anillo en el taller metalúrgico. Iba a ser un regalo de todos ellos, con la inscripción de una cita del Talmud que expresaba lo que todos los judíos del campo sentían hacia Oskar Schindler: «quien salva una vida, salva al mundo entero» ${ }^{59}$

\section{A MODO DE CONCLUSIÓN: LA NECESIDAD DE RECORDAR HOY}

Vivimos en un tiempo de olvido, de desmemoria, en el que pensamos que el pasado nada tiene que mostrarnos. Como anécdota, que Eric Hobsbawm recoge en su Historia del Siglo XX, el 28 de junio de 1992 el presidente Miterrand se desplazó de improviso a Sarajevo, escenario en el que la Guerra de los Balcanes se cobraría, en los seis meses siguientes, 150.000 vidas. El gesto de Miterrand fue recogido en diversos medios de comunicación, pero apenas nadie reparó en la importancia de la fecha: el 28 de junio de 1914 se había producido, en el mismo lugar, el asesinato del archiduque Francisco Fernando, acto que constituyó el detonante de la Primera Guerra Mundial. En palabras del historiador británico: "sólo algunos historiadores profesiona-

${ }^{59}$ Extraigo esta cita de BEST, N.: Cinco días..., p. 306. 
les y algunos ciudadanos de edad muy avanzada comprendieron la alusión. La memoria histórica ya no estaba vida", ${ }^{60}$

Nosotros aquí hemos tratado de recuperar lo que ese año de 1945 representó para tantos europeos: un año de muchas penalidades, pero también de esperanza y de mirar hacia el fututo pensando que se podía construir una sociedad mejor. ¿Cómo sintetizar este idealismo de 1945? En la Conferencia de San Francisco, celebrada el 25 de abril de 1945, se pidió al mariscal Jan Smuts redactar el preámbulo de la Carta de Naciones Unidas. Lo que dejo escrito, aunque luego fuese objeto de revisión y de trabajo de estilo, creemos que resume perfectamente este ideal. Smuts llamaba a las naciones del mundo a:

Impedir que se repita el conflicto fratricida que, por dos veces en nuestra generación, ha supuesto a la humanidad pérdidas y pesares inenarrables; restablecer la fe en los derechos humanos fundamentales; en la santidad y el valor sumo de la personalidad humana, en la igualdad de derechos entre hombres y mujeres de las naciones grandes y pequeñas; $y$ favorecer el desarrollo social y mejores condiciones de vida con mayor libertad. ${ }^{61}$

¿Ocurrió esto en el mundo? Mucho nos tememos que la respuesta ha de ser negativa. Pero en Europa, que es donde hemos encuadrado en este trabajo, la respuesta es diferente. Tenemos que establecer una división entre los dos bloques en que se separó el continente inmediatamente después de 1945, producto de las dinámicas de la Guerra Fría. En el este, cualquier intento de avanzar en esta línea, cualquier pretensión de conseguir un comunismo "de rostro más humano", fue contestada por los tanques. Pero en Europa occidental, con excepciones importantes -la más evidente, la de España, que seguía sus propias líneas históricas-, fueron años de paz y de mejoras sustanciales en el nivel de vida de la población. Los "años dorados del capitalismo", basados en un consenso social de redistribución de la riqueza y de creación de un sólido Estado del Bienestar. Alguien tan poco sospechoso de ser capitalista como Josep Fontana ha escrito hace poco: "los años que van

\footnotetext{
${ }^{60}$ HOBSBAWM, E.: Historia del..., pp. 12-13.

${ }^{61}$ Para este extracto de lo redactado por Jan Smuts, y para la Conferencia de San Franciso, se puede consultar BEST, N.: Cinco días..., pp. 123-138.
} 
de 1945 a 1975 vieron en los países desarrollados una época de conciliación social, en que un reparto más equitativo de las ganancias permitió mejorar la suerte de la mayoría. Los salarios crecían al ritmo que lo hacía la productividad, y con ellos lo hacía la demanda de bienes de consumo por parte de los trabajadores, lo que se convertía en un estímulo más para el aumento de la producción". ${ }^{62}$

Pero esta tendencia se terminó en la década de los setenta: Thatcher en Reino Unido y Reagan en Estados Unidos dieron impulso a un neoliberalismo que ha ido ganando más y más terreno desde entonces. Bajo una retórica de libertad y crecimiento, quizá su mayor "logro" las últimas décadas haya sido generar unos niveles de desigualdad absolutamente insostenibles. El economista británico Guy Standing define todo este proceso como "la corrupción del capitalismo" y recoge, en el que acaso sea el informe más llamativo al respecto, que "Oxfam estimó que en 2015 tan sólo sesenta y dos personas poseían tanta riqueza como la mitad más pobre de toda la humanidad, frente a las 388 de 2010. El 1\% de la humanidad poseía más que todo el resto del mundo en su conjunto". ${ }^{63}$ En Europa esto se ha traducido en un aumento de la inseguridad, de la precariedad, y de una menor tributación para los más ricos que conlleva el desmantelamiento de los Estados del Bienestar, bajo el mantra de la necesaria "austeridad".

Ante esta tesitura, el historiador debe proporcionar herramientas a la sociedad para que construya su memoria colectiva; y esta memoria nos dice que en 1945 se puso fin al conflicto más sangriento de la historia. Y a partir de ese año, se logró construir sociedades más justas, más prósperas, más libres; todo ello había sido precedido por un sufrimiento sin igual. Tenemos que recordar esto y, aunque el futuro sea impredecible, señalar como síntoma sumamente desasosegante que no sabemos hacia donde vamos, pero sabemos que no vamos bien. Y recordar que en 1945 existía un idealismo que

\footnotetext{
${ }^{62}$ FONTANA, J.: El futuro es un país extraño. Una reflexión sobre la crisis social de comienzos del siglo XXI. Barcelona, Pasado \& Presente, 2013, p.12.

${ }^{63}$ STANDING, G. La corrupción del capitalismo. Por qué prosperan los rentistas y el trabajo no sale a cuenta. Barcelona, Pasado y Presente, 2017, pp. 17-18. El informe en concreto es: An Economy for the 1\%, Oxfam Briefing Paper 210, enero de 2016.
} 
impulso la actividad del mundo occidental hacia una senda de mejora, y que esto se puede repetir -en otros circunstancias, por supuesto, nos enfrentamos a viejos problemas, pero también a otros totalmente nuevos: globalización, ecologismo...- conformando entre todos un nuevo proyecto social que no deje a nadie atrás. Porque cuando muchas personas son olvidadas, y el sistema niega les niega toda respuesta, se genera un vacío que rápidamente llenan los extremismos de todo signo.

Por último, incidir en un aspecto que ya ha hemos mencionado brevemente más arriba: recordar no significa mitificar. 1945 fue la culminación de unas décadas de grandes tragedias, esto hay que tenerlo claro, pero no podemos concebirlo como un punto fatídico de no retorno. En el imaginario colectivo se suele percibir como una etapa horrorosa, ya superada, a la que es imposible ya regresar. $\mathrm{Y}$ aunque el futuro es impredecible y nunca se repite en los mismos términos que el pasado, nuestro confuso presente parece dirigirnos cada vez más a nuevos escenarios de zozobra y malestar.

\section{BIBLIOGRAFÍA EMPLEADA}

AMÉRY, J.: Más allá de la culpa y la expiación. Tentativas de superación de una víctima de la violencia. Valencia, Pre-textos, 2001.

BEEVOR, A.: Berlín. La caída: 1945. Barcelona, Crítica, 2002. , La Segunda Guerra Mundial. Barcelona, Pasado \& Presente, 2014.

BEST, N.: Cinco días que estremecieron al mundo. Testigos presenciales del final de la Segunda Guerra Mundial en Europa. Barcelona, Pasado \& Presente, 2014.

BURUMA, I.: Año Cero. Historia de 1945. Barcelona, Pasado \& Presente, 2014.

DURAS, M.: El dolor. Barcelona, Alba, 1992.

ENZENSBERGER, H. M.: Europa en ruinas. Relatos de testigos oculares de los años 1944 a 1948. Madrid, Capitán Swing, 2013.

FOCILLON, H.: El año mil. Madrid, Alianza, 1966.

FONTANA, J.: Por el bien del Imperio. Una historia del mundo desde 1945. Barcelona, Pasado \& Presente, 2013. , El futuro es un país extraño. Una reflexión sobre la crisis social de comienzos del siglo XXI. Barcelona, Pasado \& Presente, 2013. 
, El siglo de la Revolución. Una historia del mundo desde 1914. Barcelona, Crítica, 2017.

GROSSMAN, V.; EHRENBURG, I.: El libro negro. Barcelona, Galaxia Gutenberg, 2011.

GROSSMAN, V.: El infierno de Treblinka. Barcelona, Galaxia Gutenberg, 2014.

HESSEL, S.: Mi baile con el siglo. Memorias. Barcelona, Destino, 2011.

HOBSBAWM, E.: Historia del siglo XX. Barcelona, Crítica, 2005.

JUDT, T.: Sobre el olvidado siglo XX. Madrid, Taurus , 2008.

, Postguerra: una historia de Europa desde 1945. Madrid, Taurus, 2012.

KOESTLER, A.: El cero y el infinito. Buenos Aires, Emecé, 1960.

KOGON, E.: El Estado SS. El sistema de los campos de concentración alemanes. Barcelona, Alba, 2005.

LEVI, P.: Trilogía de Auschwitz. Barcelona, Península, 2015.

LEWIS, N.: Nápoles 1994: un oficial del Servicio de Inteligencia en el laberinto italiano. Barcelona, RBA, 2012.

SEMPRÚN, J.: Ejercicios de supervivencia. Barcelona, Tusquets, 2016.

STANDING, G. La corrupción del capitalismo. Por qué prosperan los rentistas y el trabajo no sale a cuenta. Barcelona, Pasado y Presente, 2017.

STEVENSON, D.: 1914-1918. Historia de la Primera Guerra Mundial. Barcelona, Círculo de lectores, 2013.

TOMÁS Y VALIENTE, F.: A orillas del Estado. Madrid, Taurus, 1996.

WACHSMANN, N.: KL. Historia de los campos de concentración nazis. Barcelona, Crítica, 2015.

WALKER, J.: Operación «Impensable». 1945: los planes secretos para una tercera guerra mundial. Barcelona, Crítica, 2015. 